\title{
ON THE VARIATION AND ECOLOGY OF PTERYGONEURUM SUBSESSILE AND P. KOZLOVII (POTTIACEAE, BRYOPHYTA)
}

\section{ОБ ИЗМЕНЧИВОСТИ И ЭКОЛОГИИ РТЕRYGONEURUM SUBSESSILE И Р. KOZLOVII (POTTIACEAE, BRYOPHYTA)}

\author{
Olga Yu. Pisarenko ${ }^{1}$ \\ ОЛЬГА Ю. ПИСАРЕНКО ${ }^{1}$
}

Abstract

\begin{abstract}
Pterygoneurum kozlovii, a rare species worldwide, is found in Altaisky Territory, Kazakhstan and Central Yakutia, mainly in halophytic habitats. Study of morphology and anatomy of $P$. subsessile and $P$. kozlovii reveals certain intergradation between typical morphotypes of these two species. Quantitative characteristics of plants and their illustrations are given, demonstrating complex situation in this group.
\end{abstract}

Резюме

Pterygoneurum kozlovii, повсеместно редкий вид, выявлен во многих местонахождениях в Алтайском крае, Казахстане и Центральной Якутии, преимущественно в засоленных местообитаниях. Морфологическое и анатомическое изучение образцов показало наличие промежуточных морфотипов между типичными $P$. subsessile и $P$. kozlovii. Результаты измерений и иллюстрации показывают более сложные взаимоотношения в группе P. subsessile - P. kozlovii.

INTRODUCTION

In the course of identification of Pterygoneurum collections from the Altaisky Territory (south of West Siberia), the problem of differentiation of Pterygoneurum subsessile (Brid.) Jur. and P. kozlovii Laz. appeared. Typical morphotypes of these two species of Pterygoneurum with immersed capsules are quite distinct: $P$. subsessile is stegocarpous moss; its tufts are grayish and hoary due to very long hyaline hairs points; P. kozlovii is cleistocarpous, its leaves have short hyaline hairs points, tufts are yellowish-green (Ignatov \& Ignatova, 2003). However a number of intermediate plants, which are difficult to interpret were found as well.

Pterygoneurum subsessile is a rather common species of xeric regions, widely distributed in central and southern Europe; in northeastern, eastern, central and southwestern Asia; in northern Africa; in North, Central and South America. In European Russia it is common in south-eastern provinces, sporadic in Central Chernozemje and in South Urals; in Siberia it occurs mainly in its southern part - in xeric areas of Altai Mts., West Sayan Mts., near Baikal Lake; in steppes of Altaisky Territory, Minusinsk and Tuva depressions, Chulym-Yenisei depression and Dauria; also it occurs in Central Yakutia and further to the north it is recorded in subarctic regions in the middle course of Indigirka River and on Putorana Plateau.

Pterygoneurum kozlovii is a rare species; known in the world only in a few localities (Fig. 1). It was described from Ukraine (Lazarenko, 1946), where it occurs in Zaporozh'e (Lazarenko, 1955) and Odessa (Bachurina, 1960) Provinces. Similar cleistocarpous Pterygoneurum species was described from Czechoslovakia (Vanek, 1952) as P. smardaeanum Vanek; later it was synonymized with $P$. kozlovii (Abramova \& al., 1973). Then P. kozlovii was recorded for Romania (Wallfisch, 2001), Mongolia (Abramova \& Tsegmed, 1989; Tsegmed, 2001), China (Tan, Zhao \& Hu, 1995), Canada, inland areas of British Columbia (McIntosh, 1989). In Russia it is known from Saratov (Cherepanova, 1971) and Rostov (Babenko \& Fedyaeva, 2001) Provinces and from continental Siberia in north Yakutia, Indigirka River (Afonina \& al., 1979). [cont. p. 172]

1 - Central Siberian Botanical Garden, Zolotodolinskaya 101, Novosibirsk 630090 Russia - Россия 630090 Новосибирск, Золотодолинская, 101, Центральный Сибирский ботанический сад СО РАН 
Table 1. Occurrence of Pterygoneurum-specimens in plant communities (described below):

\begin{tabular}{|c|c|c|c|c|c|c|c|c|c|c|c|c|c|c|}
\hline $\begin{array}{l}\text { Type of plant community } \\
\text { Releve field number }\end{array}$ & $\begin{array}{l}\text { I } \\
\text { at04 }\end{array}$ & $\begin{array}{l}\text { I } \\
\text { at0\& }\end{array}$ & $\begin{array}{l}\text { I } \\
8 \text { at09 }\end{array}$ & $\begin{array}{l}\text { I } \\
\text { at1 }\end{array}$ & $\begin{array}{l}\text { I } \\
0 \text { at11 }\end{array}$ & $\begin{array}{l}\text { I } \\
\text { at13 }\end{array}$ & I & $\begin{array}{l}\text { II } \\
4 \text { at02 }\end{array}$ & $\begin{array}{l}\text { II } \\
\text { at07 }\end{array}$ & $\begin{array}{l}\text { II } \\
7 \text { at00 }\end{array}$ & $\begin{array}{l}\text { III } \\
\text { at12 }\end{array}$ & $\begin{array}{l}\text { IV } \\
\text { at05 }\end{array}$ & $\begin{array}{l}\mathrm{V} \\
\mathrm{y} 00\end{array}$ & $\begin{array}{l}\text { VI } \\
\text { k19 }\end{array}$ \\
\hline Collecting point & 7 & 4 & 4 & 4 & 3 & 2 & 2 & 8 & 5 & 1 & 3 & 6 & $9-Y$ & $10-\mathrm{K}$ \\
\hline 'typical P. subsessile' & . & . & . & 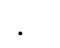 & 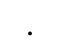 & . & + & 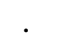 & + & + & . & + & + & + \\
\hline 'atypical P. subsessile' & $\cdot$ & + & + & + & + & + & . & + & . & . & + & . & . & . \\
\hline 'debatable $P$. kozlovii' & 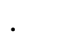 & . & . & $\cdot$ & . & $\cdot$ & + & $\cdot$ & + & . & + & $\cdot$ & . & . \\
\hline 'typical P. kozlovii' & + & + & + & + & . & . & . & + & . & . & . & . & + & . \\
\hline ? from Kazakhstan & $\cdot$ & $\cdot$ & . & . & . & . & . & . & . & . & . & . & . & + \\
\hline Pterygoneurum ovatum & 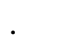 & . & . & . & . & . & . & + & . & . & . & + & . & . \\
\hline Phascum cuspidatum & $\cdot$ & . & . & . & $\cdot$ & . & . & $\cdot$ & . & . & . & + & . & . \\
\hline Bryum argenteum & 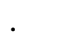 & + & . & . & + & + & + & + & + & . & + & + & $\cdot$ & . \\
\hline Ceratodon purpureus & . & . & . & 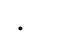 & . & • & . & + & . & . & $\cdot$ & + & . & . \\
\hline Entostodon hungaricus & . & . & . & 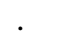 & . & . & . & + & + & . & . & . & . & . \\
\hline Funaria hygrometrica & . & 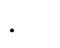 & + & . & . & . & 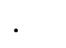 & $\cdot$ & . & . & . & . & . & 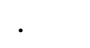 \\
\hline Bryum sp. & + & . & . & . & . & . & 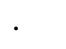 & + & . & . & 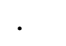 & + & 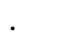 & \\
\hline
\end{tabular}

I-IV halophyte communities from Altaisky Territory (steppe zone):

I - communities of small perennial halophyte succulent semishrabs.

The communities are poor in species (6-15 high vascular species per releve); herb layer is rarefied (cover 30-60\%). Perennial semishrabs Artemisia nitrosa Web. ex Stechm., Halocnemum strobilaceum (Pall.) Bieb., Halimione verrucifera (Bieb.) Aell., Limonium suffruticosum (L.) O.Kuntze prevail. Puccinellia tenuissima Litv. ex V. Krecz. usually abundant. Annual herbs Limonium gmelinii (Willd.) O.Kuntze, Bassia setoides (Pall.) Aschers., Ofaiston monandrum (Pall.) Moq., Salicornia perennans N. Semen., Suaeda prostrata Pall., Petrosimonia litwinowii Korsh. are common and often abundant. Habitat salinization in ecological scale of L. G. Ramenskij is 20-21 degree, humidification is 37-43 degree. In Braun-Blanquet classification the communities belong to the association Artemisio nitrisae-Halimionietum verruciferae Korolyuk 1999 (class Salicornietea fruticosae (Br-Bl. et.R.Tx.1943) R.Tx et Oberd. $1958 \mathrm{em}$. Golub et V.Slkh. 1988; order Halostachyetalia Topa 1939 em Golub et Tchorbadze 1987; union Climacoptero-Suaedion Golub et Tchorbadze 1989). Such communities are the most common halophyte vegetation type in West Siberian steppe zone. They occupy large areas on saline plains, on terraces of saline lakes, and on ancient gullies that became saline. The communities are situated on up-raised and the least salted sites among solonchaks (Korolyuk, 1999); frequently they contact with monodominant halophyte communities along shores of saline lakes and in place of temporary lakes flooding seasonally during spring time. In the last communities mosses were not found.

II - solonetz steppes with abundance of Artemisia species.

Herb layer is poor in species and rarefied, cover is 5060\%. Puccinella tenuissima Litv. ex V. Krecz. prevalils, gramineous plants Elytrigia repens (L.) Nevski, Psathyrostachys juncea (Fisch.) Nevski and Artemisia nitrosa
Web., A. austriaca Jacq, A. rupestris L., A. scoparia Waldst. et Kit. are abundunt. Halophytes Limonium gmelinii, Kochia prostrata (L.) Schrad. and others present. Habitat salinization is about 15-17 degree, humidification vary from 44 to 52 degree. In Braun-Blanquet classification the communities belong to union Artemision nitrosae Korolyuk in Korolyuk et Kipriyanova 1998 (class Festuco-Puccinellietea Soo ex Vicherek 1973, order Festuco valesiacae-Limonietalia gmelinii Mirkin in Golub et V. Solomakha 1988). In southern West Siberia such communities participate in vegetation mosaic of saline territories. They occur on crust and shallow solonetzs (Korolyuk, 1993; Korolyuk, Kiprijanova, 1998; Golub, Karpov, Sorokin, Nikolajchuk, 2005).

\section{III - bunchgrass solonetz steppe.}

The appearance of the community is created by tall tussocks of Stipa capillata L. and Achnatherum splendens (Trin.) Nevski; in lower layer Festuca valesiaca Gaudin, Cleistogenes squarrosa (Trin.) Keng, Artemisia frigida Willd. prevail; halophytes Puccinella tenuissima, Limonium gmelinii and others are not numerous. Habitat salinization is about 15 degree, humidification is about 48 degree. In Braun-Blanquet classification the communities as previous belong to order Festuco valesiacae-Limonietalia gmelinii (class Festuco-Puccinellietea).

IV - solonetz community with prevailing Poaceae and Artemisia species.

Tussock gramineous species Psatyrostachys hyalantha (Rupr.) Tzvel., Leymus ramosus (Trin.) Tzvel., Stipa lessingiana Trin. et Rupr., Festuca valesiaca prevail. Artemisia species - Artemisia gracilescens Krasch. et Iljin, A. austriaca, A. frigida and xerophytes semishrabs Atriplex cana C.A.Mey, Camphorosma lessingii Litv. are abundant (Korolyuk, Pristiaznyuk, Platonova, 2000). Habitat salinization is about 14-15 degree, humidification is about 4043 degree. In Braun-Blanquet classification the community belongs to union Stipion korshinskii Toman 1969 (class Festuco-Brometea Br.-Bl. et Tx. 1943, oder Helictotricho-Stipetalia Toman 1969). 


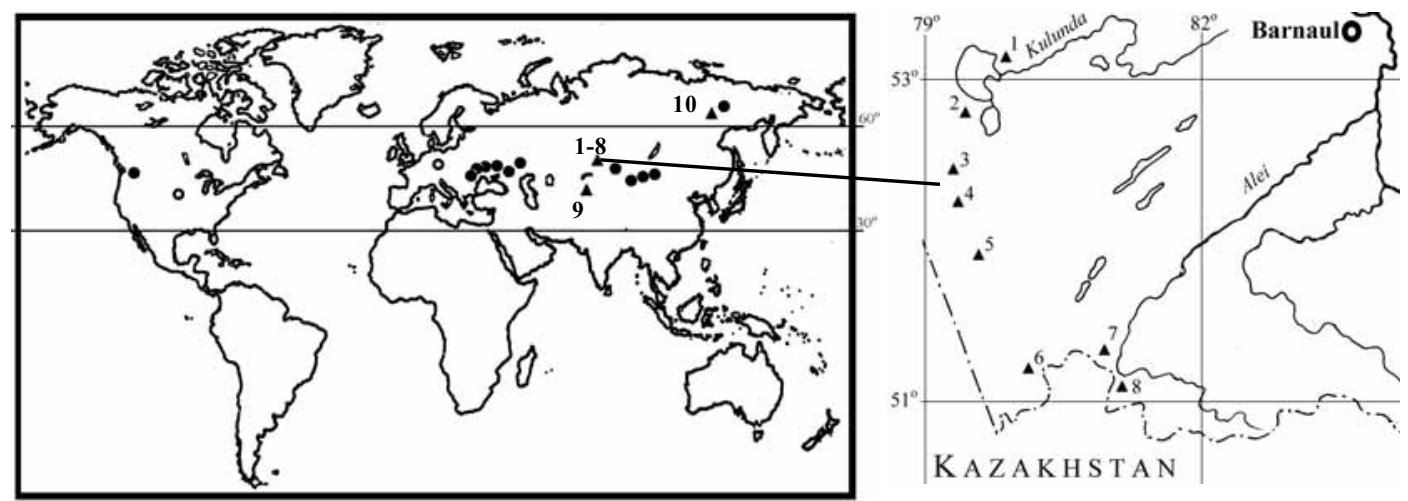

Fig. 1. Distribution of Pterygoneurum taxa. Filled circles - literature records of $P$. kozlovii Laz.; open circle in Europe $-P$. smardeanum Vanek; open circle in North America - P. subsessile var. kieneri Habeeb. Triangles -author's data, listed below:

$1 \quad$ Localities

1 Blagoveshchenka Distr.,

Kulunda Lake

Bauzansor Lake

3 Kljuchi Distr., Krivaja Puchina Lake

4 Kljuchi Distr., Petukhi

5 Mihajlovskoje Distr., between Nikolajevka and Nazarovka

6 Uglovskoje Distr., Bolshoj Tassor Lake

7 Rubzcovsk Distr., Veselojarsk

8 Lokot Distr., Novenkoje

9 Yakutsk area, Vladimirovka

10 Alma-Ata Region, Chu-Ili Mts
Lat-Lon

$53^{\circ} 05^{\prime} \mathrm{N}$

$79^{\circ} 50^{\prime} \mathrm{E}$

$79^{\circ} 28^{\prime} \mathrm{E}$

$52^{\circ} 26^{\prime} \mathrm{N}$

$79^{\circ} 22^{`} \mathrm{E}$

$52^{\circ} 13^{\circ} \mathrm{N}$

$79^{\circ} 28^{\circ} \mathrm{E}$

$51^{\circ} 59^{\prime} \mathrm{N}$

$79^{\circ} 28^{\prime} \mathrm{E}$

$51^{\circ} 14^{\circ} \mathrm{N}$

$80^{\circ} 22^{\circ} \mathrm{E}$

$51^{\circ} 15^{\circ} \mathrm{N}$

$81^{\circ} 04^{\circ} \mathrm{E}$

$51^{\circ} 01^{\circ} \mathrm{N}$

$81^{\circ} 15^{\circ} \mathrm{E}$

$61^{\circ} 45^{\circ} \mathrm{N}$

$129^{\circ} 32^{`} \mathrm{E}$

$43^{\circ} 55^{\circ} \mathrm{N}$

$75^{\circ} 21^{\circ} \mathrm{E}$
Alt, m Releve number; date Number in Fig. 2 - collector number

\section{Altaisky Territory}

110 at00; 9.VI.1995

$4-$ op01109

96 at13-14; 21.IX.2003

5 - op00813

8 - op01104

$14,15,16$ - op00814

124 at11-12; 20.IX.2003

7,17 - op01108

12 - op01103

127 at8-10; 19.IX.2003

9,23 - op00445

10 - op01101

13,19 - op01107

22 - op01102

$6-$ op01105

$18-$ op01106

3 - op01110

227 at04; 15.IX.2003

$21-$ op00804

249

at02; 14.IX.2003

$11-$ op00802

20 - op00803

\section{Yakutia}

y00; 27.VI.2006

\section{1}

24

\section{Kazakhstan}

820

k19; 19.V.2005

\section{2} 25

\section{V - Central Yakutia, steppe on steep slope to}

\section{Lena River valley.}

The herbage is rich and dense. From Poaceae-species Koeleria cristata (L.) Pers., Festuca lenensis Drob., Poa stepposa (Kryl.) Rohev., Stipa krylovii Roshev are abundant. Forbs are diverse: Diantus versicola Fisch. ex Link, Veronica incana L., Lychnis sibirica L., Galium verum L., Pulsatilla flavescens (Zucc.) Juz., Potentilla bifurka L. and others. In Braun-Blanquet classification the community belongs to class Cleistogenetea squarrosae Mirk. et al. 1986.
VI - Kazakhstan, low Chu-Ili Mts., petrophytic desert in solonchak surroundings.

Few halophyte and petrophyte perennial plants - Salsola arbusculiformis Drob., Anabasis salsa (C.A. Mey.) Benth. ex Volkens, Nanophyton erinaceum (Pall.) Bge., Camphorosma sp., Artemisia juncea Kar. et Kir., A. sublessingiana Krasch. ex Poljak.are presented by solitary specimens. Aspect is crated by ephemeroid Poa bulbosa L.; tiny annual ephemers are numerous - Eremopyrum buonapartis (Spreng.) Nevski., Ziziphora tenuior L. and others. 
Descriptions of $P$. kozlovii in different publications (based on different specimens) are somewhat inconsistent. For example, ventral lamellae are described as short, 2-5 cells high (Abramova $\&$ al., 1973) or tall - 6-11 cells high (Ignatov \& Ignatova, 2003, Fig. 214, p.305). Laminal cells are described as papillose on both sides (Abramova $\&$ al., 1973), as weakly papillose on dorsal side (Ignatov \& Ignatova, 2003) and as smooth (Zander, 2003). In description of Abramova \& al. (1973, p. 311): 'capsule is not dehiscent; operculum is delimited from capsule by only 2-4 rows of smaller cells' (further in the article the cells named 'marking cells'). However Zander (1. c.) stated, in contrary, that the distinguishing feature of $P$. kozlovii is the absence of such cells, as opposed to P. subsessile var. kieneri Habeeb (see also Habeeb, 1949). The latter variety has 'capsule facultatively cleistocarpous: annulus differentiated but operculum remains attached and spores are releasing through the ruptured capsule walls. This taxon is P. subsessile with possibly hybrid sporophytes. Two forms with identical gametophytes were present in the type collection, one with typical sporophyte, the other with that of the variety. The operculum is not dehiscent and the capsule bursts irregularly. The sporophyte apparently falls as a unit, breaking off at the base of the seta' (Zander, 2003).

My collections of Pterygoneurum with immersed capsules were found to be morphologically heterogeneous. Besides typical P. subsessile and $P$. kozlovii, there were intermediate plants. In the present study we tried to define more clearly the distinguishing characters between these species and interpret these transitional morphotypes.

\section{MATERIAL AND METHOD}

Morphological studies are based mainly on collections of 2003 for geobotanical releves of halophyte plant communities in Altaisky Territory (southern West Siberia, Fig. 1). The territory is situated within the steppe zone and vast areas in its western part are saline; different variants of saline soils and halophyte communities replace each other according to weak differences in relief position and, correspondingly, according to differences in amount of migrated water and soluble salts. The material was collected within one week, so the plants were approximately at the same stage of development. In summer 2006 some Pterygoneurum samples were collected near Yakutsk on steppe slope. In addition Pterygoneurum samples of 2005 from steppe and desert communities of Kazakhstan were studied. All samples are in Bryophyte Herbarium of Central Siberian Botanical Garden, Novosibirsk (curator O. Yu. Pisarenko).

Most collections from non-halophytic habitats were found to be fairly homogeneous and fit well to Pterygoneurum subsessile. However a preliminary look at a number of collections, especially from saline habitats, suggests the presence of two species. In the latter case two groups of plants were taken off the tuft (in one case four superficially distinct plants), one being most 'typical subsessile' (plants greyish, leaves with long hyaline hair-point, stegocarpous), whereas another being maximally 'typical kozlovii' (plants greenish, leaves with short hyaline hair-points, cleistocarpous). Each of these groups were analyzed for qualititative characters, while all measurements were made from slides of one best developed plant that fits the following requirements: (1) presence of calyptra and mature capsule of 'normal' shape (in stegocarpous plants at the stage of beginning of operculum separating, and in cleistocarpous plants - with just scarce breakage of capsule walls); (2) plants not much buried in the soil, thus possessing at least 5 large leaves totally above soil level; (3) all hyaline hairpoints not broken. Measurements were done using 5 leaves, starting from lower leaf with welldeveloped hyaline hair-pont up to perichaetial one. Cross-sections were done from these leaves after their measurements. Lamellae height was counted in the widest part of a leaf (Fig. 2 displays minimal and maximal height of lamellae at this place). Cells were measured in the area shown in Fig. 6. Among the characters studied were also spore size; beak length and seta length above vaginula (measured in slides of sporophytes in water) ; exothecial cell size in the midcapsule; size of cells at capsule mouth and operculum margin for stegocarpous plants and size of marking cells, if present, for cleistocarpous plants (in cell measurements the smallest and the biggest values were recorded). Also for every plant calyptra shape, number of lamellae, their shape, laminal cell papillosity and awn serrulation were estimated. 


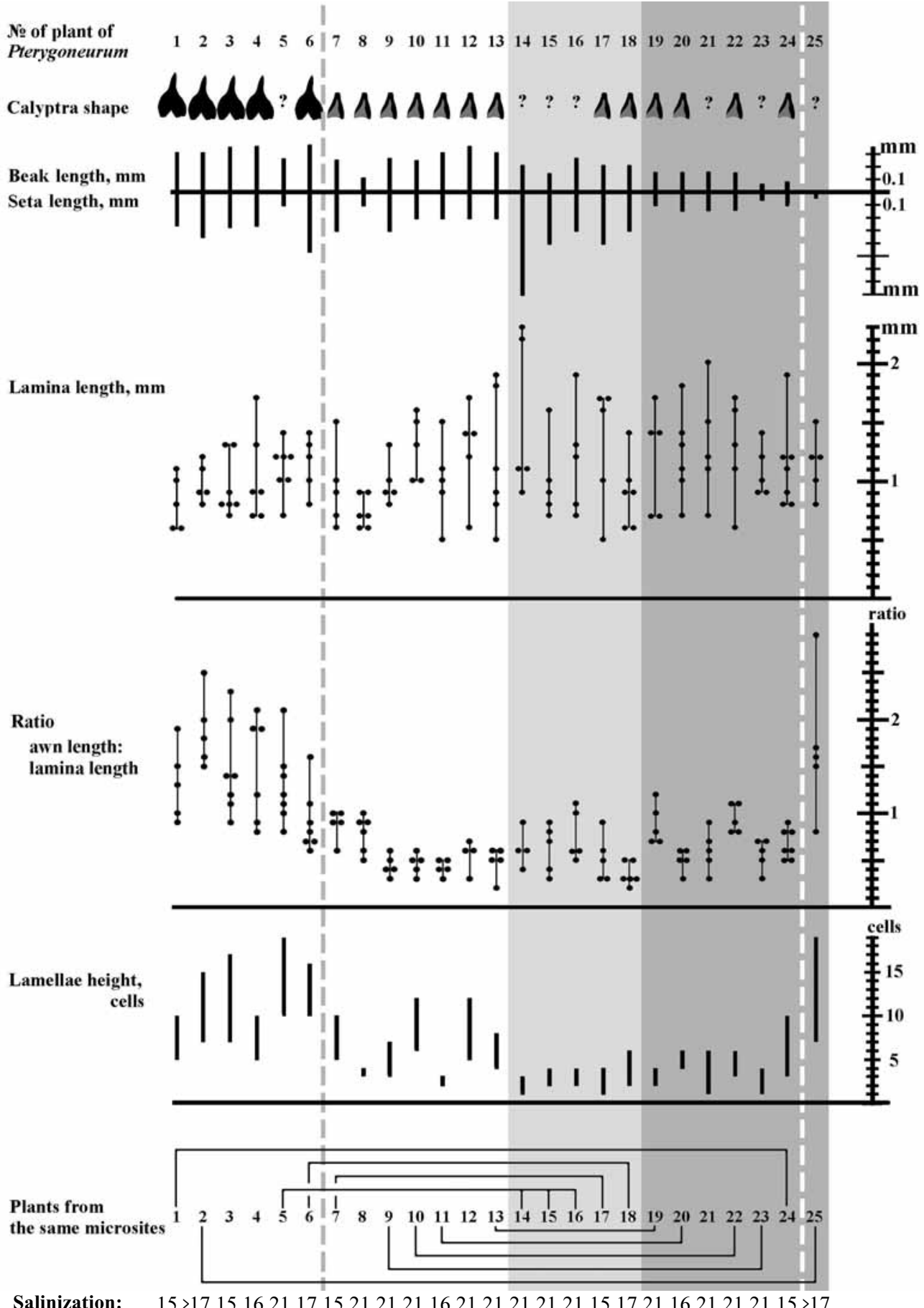

Fig. 2. Bar graphs of variations of some morphological parameters in different plants of Pterygoneurum subsessile (Brid.) Jur. and P. kozlovii Laz., description in text. White background is for stegocarpous plants, grey background is for cleistocarpous plants (light-grey for plants with marking cells in caplula; deep-grey for plants without marking cells). (1, 24 - from Yakutia; 2, 25 - from Kazakhstan; the localyties are under table 1. 3-23 from Altaisky Territory. Herbarium numbers of the samples and localities are in explanation of Fig. 1). Plants from the same microsites are connected by brackets. 


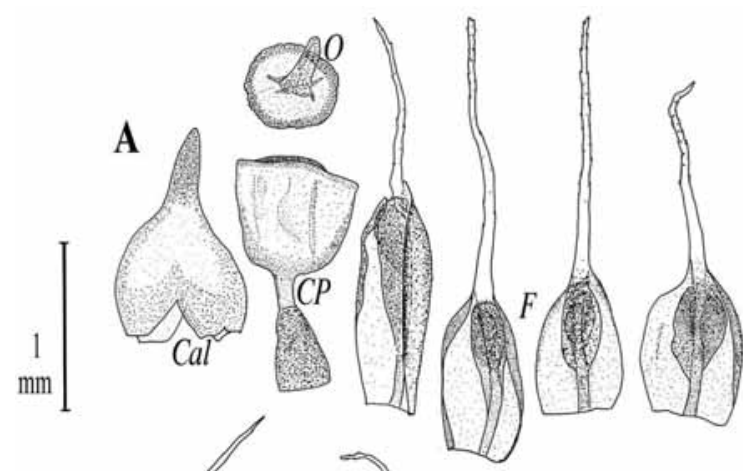

Fig. 3. Leaves $(F)$, capsules $(C P)$, operculums $(O)$ and calyptras $(\mathrm{Cal})$ from different plants of Pterygoneurum subsessile and P. kozlovii. A - "typical P. subsessile", B-C - "atypical P. subsessile", DE- "debatable P. kozlovii", F-I - "typical P. kozlovii"; $\mathrm{J}$-Kazakhstanian cleistocarpous Pterygoneurum; description in text. (A-H from Altaisky Territory: A from plant 4 (cf. Table 1 and Fig. 2), B - from 9, C7, D - 14, E - 17, F - 23, G - 22, H - 20. I - from Yakutia, 24. J - from Kazakhstan, 25.)

B
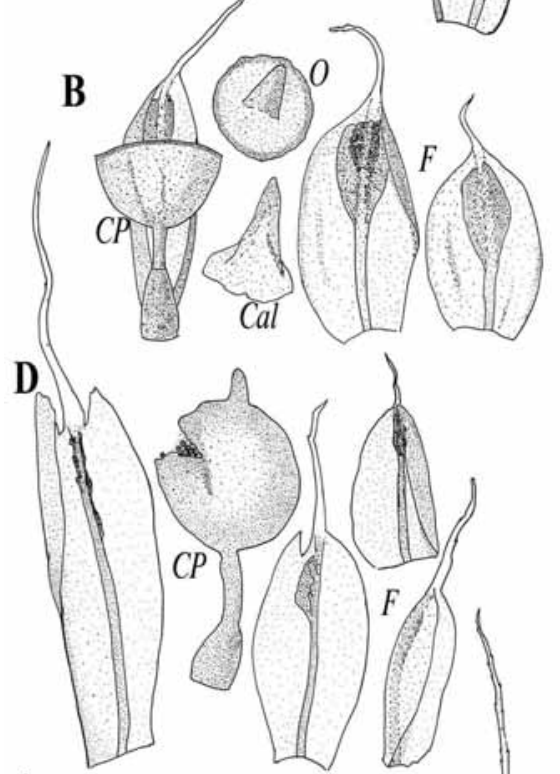

F

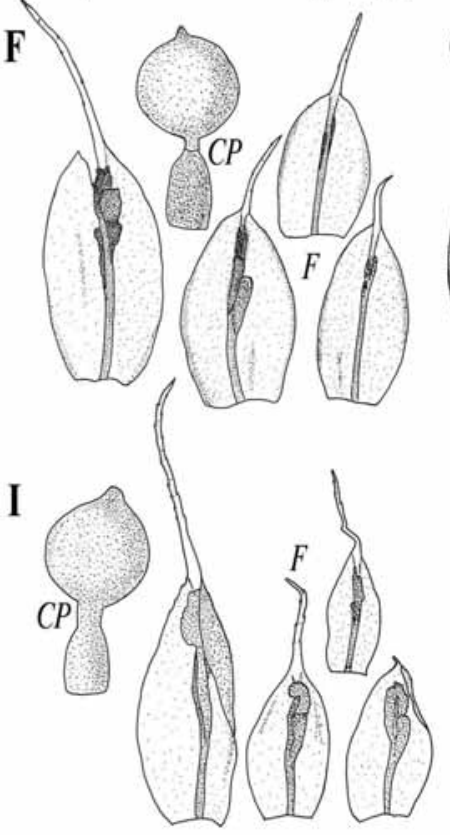

C

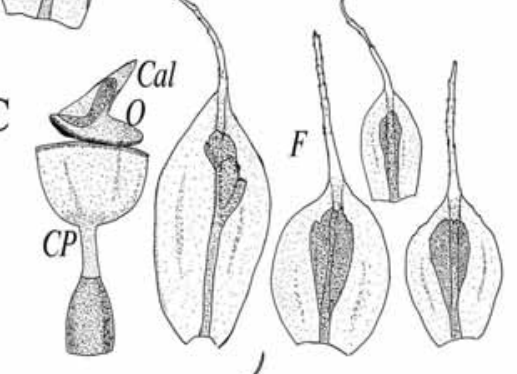

E

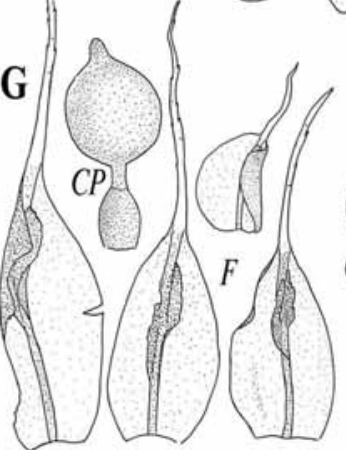

L
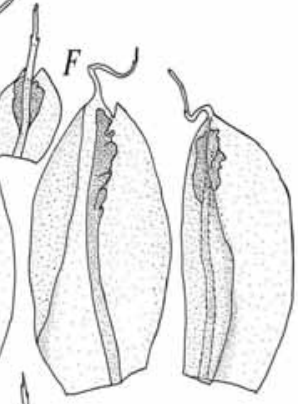

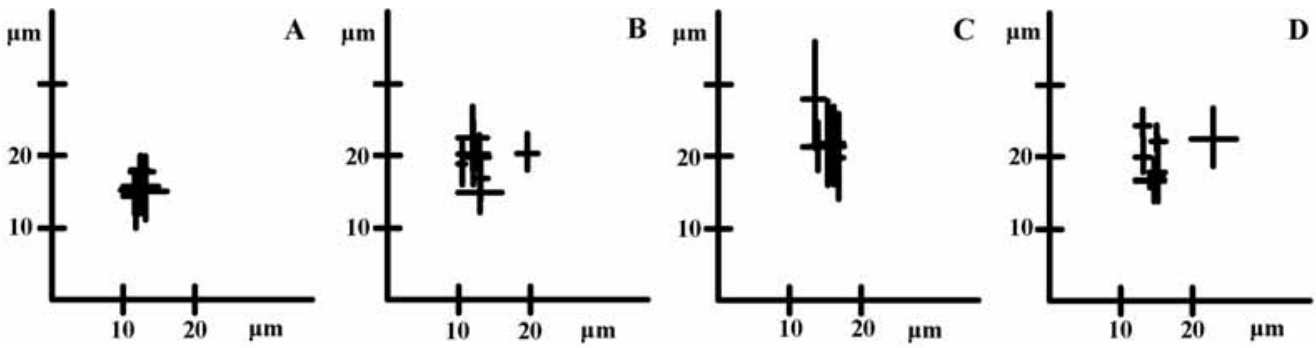

Fig. 4. Variations of mid-leaf cells of Pterygoneurum subsessile (Brid.) Jur. and P. kozlovii Laz.; X - cell width, Y- cell length. A - "typical P. subsessile", B - "atypical P. subsessile", C - "debatable P. kozlovii", D " typical P. kozlovii".

Habitat salinization and humidification were determined according to ecological scales of L. G. Ramenskij (Methodical ..., 1974; Korolyuk, 2000) that are more detailed in comparison with Ellenberg' scales (their correlation is given by Samoilov, 1973). In Ramenskij' scale of the soil prolificacy and salinity has 1-30 degrees, from oligotrophic soils (degree 1-3) to extreme solonchak soils (degree 29-30). Investigated sites (see legend of Table 1) have 'rich soils' (degree 14-16: pH 7.0-7.5, no salts poisonous for plants), 'weakly saline soils' (degree 17-19: $\mathrm{pH}$ 7.5-8.3, minute amount of sulphates and chlorides), and 'average saline soils' (degree 20-21: $\mathrm{pH} 7.5-8.3$, in aqueous extract 0.1$0.3 \% \mathrm{SO}_{4}^{2-}$ and $0.05-0.1 \% \mathrm{Cl}^{-}$).

\section{RESULTS}

The collected data were not enough for statistic analysis, mainly due to limited number of cleistocarpous plants. Moreover, the clesitocarpous populations appear to be more heterogeneous than it was expected. So the studied samples were classified into five groups according to their morphological characters (Figs. 2-5).

1) 'typical P. subsessile' (Fig. 2, columns 1-6; Fig. 3 A; Fig. 5 A; Fig. 6 A). Tufts grayish and hoary. Leaves $0.6-1.3 \times 0.4-0.8 \mathrm{~mm}$ (perichaetial leaves bigger, up to $1.7 \times 0.8 \mathrm{~mm}$ ), with long serrulate hyaline awn. Awn 0.6-1.8(-2.1) mm long, usually longer than lamina, the ratio awn:lamina length (0.8-)1-2(-2.3). Median laminal cells quadrate to shortly rectangular, 9-16 x 11-20 $\mu \mathrm{m}$; smooth to weakly mamillose or papillose on dorsal side. Ventral lamellae (2-)4, from 5-7 to 1015(-19) cells high. Lamella cells smooth to mamillose. Calyptra mitrate. Seta above vaginula 0.1$0.4 \mathrm{~mm}$ long. Operculum separating, with beak up to $0.3 \mathrm{~mm}$ long. Operculum marginal cells in 2-3 rows small, quadrate to shortly rectangular, from $9-16 \times 9-16$ to $16-23 \times 21-27 \mu \mathrm{m}$; above cells bigger, $27-40 \times 36-70 \mu \mathrm{m}$. Urn cells in 2-3 rows below mouth small, $9-16 \times 18-27 \mu \mathrm{m}$, rather abruptly delimited from exothecial cells (23$36 \times 50-90 \mu \mathrm{m}$ in mid-urn).

The plants from Altaisky Territory (Fig. 2, columns 3-6) and Yakutia (Fig. 2, column 1) and Kazakhstan (Fig. 2, column 2) are similar and are in agreement with the species descriptions (SaviczLubitskaya \& Smirnova, 1970; Ignatov \& Ignatova, 2003). The same appearance has a specimen from Novosibirsk Province (Salair Range, Pisarenko, 9.VII.1993).

2) 'atypical P. subsessile' (Fig. 2, columns 713; Fig. 3, B-C; Fig. 5 B-D; Fig. 6 B). Tufts yellowish-green, not hoary. Leaves $0.6-1.5 \times 0.3-1$ $\mathrm{mm}$ (perichaetial leaves up to $1.8 \times 1.1 \mathrm{~mm}$ ), with relatively short and weakly serrulate hyaline awn. Awn 0.3-0.9(-1.1) mm long, usually shorter than lamina; the ratio awn:lamina length (0.2-)0.3-1. Median laminal cells quadrate to shortly rectangular, 9-16 x (12-)14-25(-27) $\mu \mathrm{m}$; smooth to mamillose or papillose on dorsal side (one sample has rather bigger cells - 18-21 x 18-23 $\mu \mathrm{m}$ ). Ventral lamellae 2 to 4, 2-12 cell high; lamellae number, shape and size often variable in leaves of one plant; in lower leaves lamellae usually short. Lamellae cells smooth to mamillose. Calyptra cucullate. Seta above vaginula 0.1-0.3 mm long. Operculum separating, with beak 0.1-0.3 mm long. Operculum often have uneven, 'jagged' margin; marginal cells in 2-3 rows small, quadrate to shortly rectangular, from 8-16 x 9-18 to $16-27 \times 18$ $27(-37) \mu \mathrm{m}$; above cells larger, $18-32 \times 33-63 \mu \mathrm{m}$. Urn cells in 2-3 rows below mouth small, 9-14(19) $x 9-25 \mu \mathrm{m}$; abruptly delimited from exothecial cells [ 23-36 x (36-)54-70(-100) $\mu \mathrm{m}$ in midurn]. 


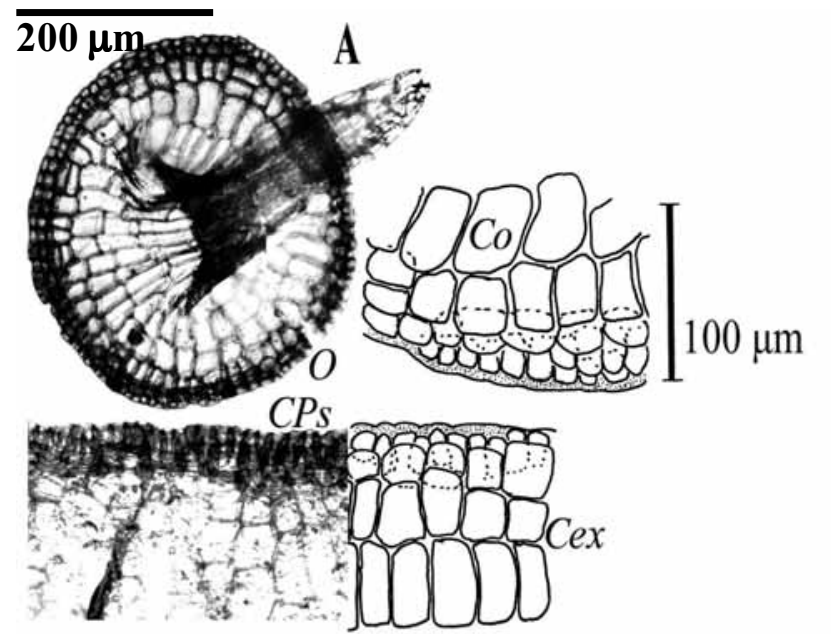

Fig. 5. Upper parts of capsules (CPs), operculums $(O)$, exothecial cells $(\mathrm{Cex})$ and operculum border cells $(\mathrm{Co})$ from different plants of Pterygoneurum subsessile (Brid.) Jur. and P. kozlovii Lazar.. A - "typical $P$. subsessile", B-D - "atypical P. subsessile", E-G - "debatable P. kozlovii", H-J - " typical P. kozlovii", K - Kazakhstan cleistocarpous Pterygoneurum; description in text. Scale bar $100 \mu \mathrm{m}$ for Co-Cex. 200 $\mu \mathrm{m}$ for $O, C P s$.

(A from Central Yakutia, 1. B-J from Altaisky Terrytory: B - from plant 7, C -10 , D - 9, E - 17, F - 14, G - 18, H - 19, I - 22, J -23 . K from Kazakhstan, 25)
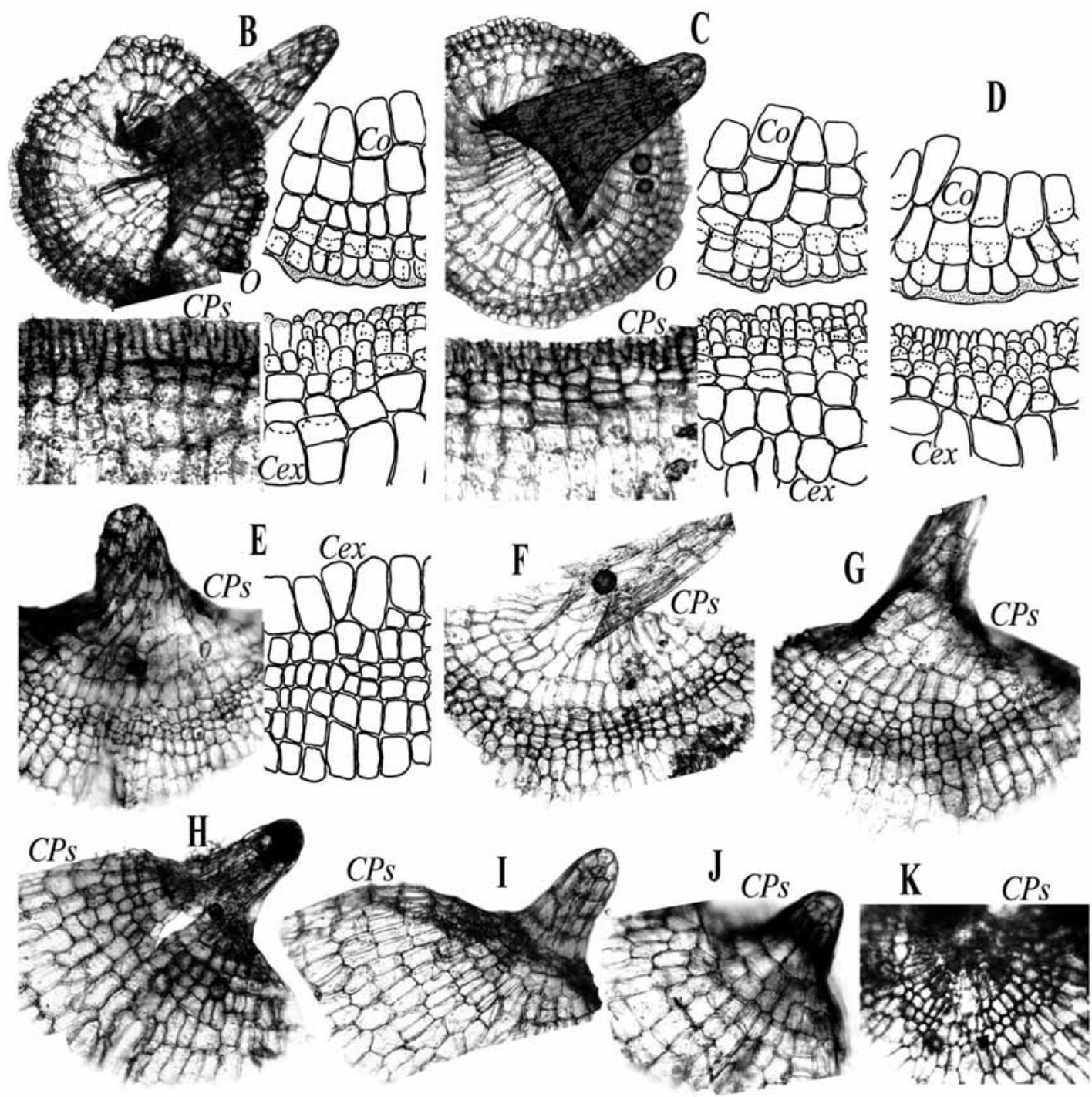


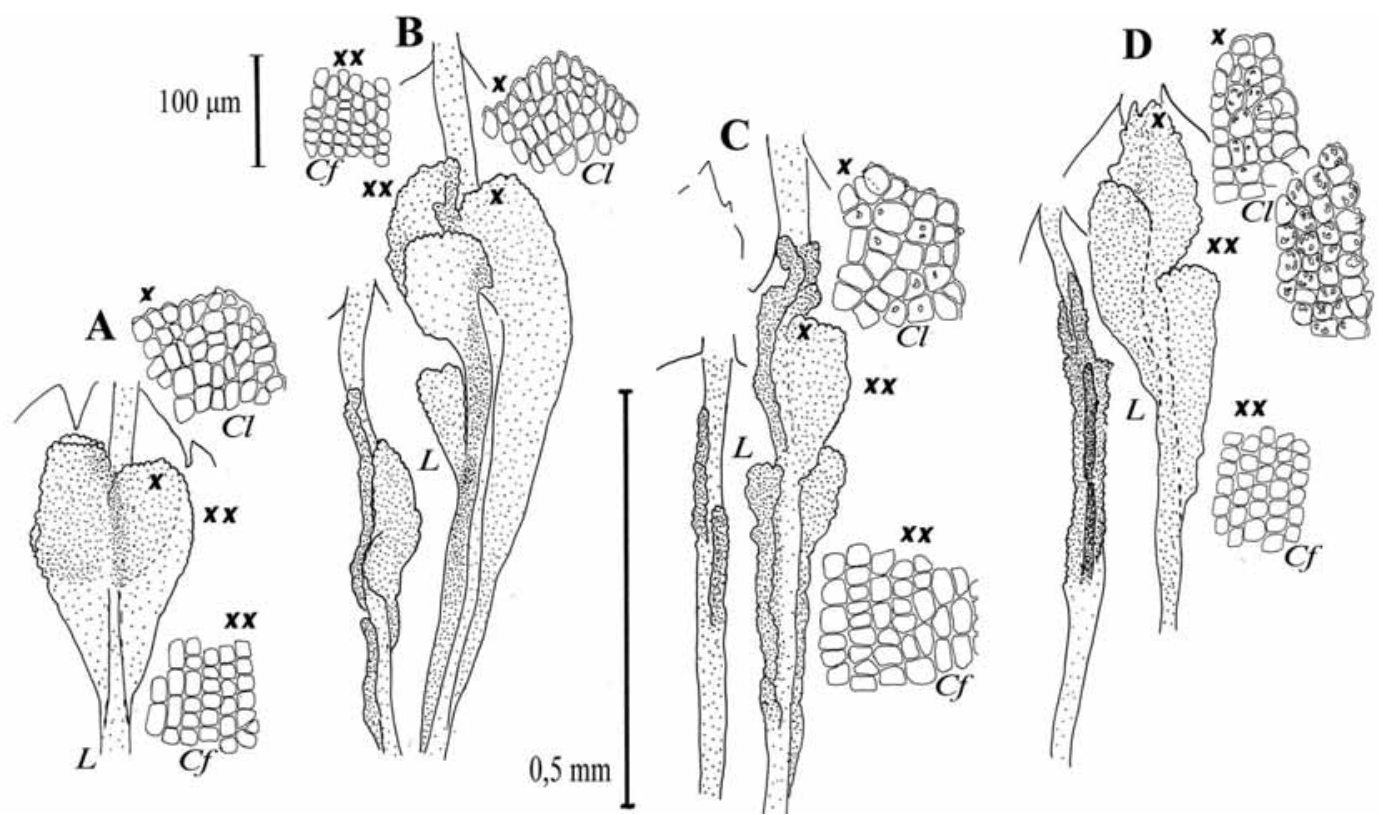

Fig. 6. Costa with lamellae $(L)$, areolation of lamellae $(C l)$ and lamina cells of mid-leaf $(C f)$ from different plants of Pterygoneurum subsessile (Brid.) Jur. and P. kozlovii Laz. A - "typical P. subsessile", B - "atypical $P$. subsessile", C-D - "typical P. kozlovii", description in text. Scale bars: $0,5 \mathrm{~mm}-$ for $L ; 100 \mu \mathrm{m}-$ for $C l$ and $C f$. (A\&D - from Central Yakutia; A - from plant 1, D - 24. B\&C - from Altaisky Terrytory, from plants 9 and 23).

So, these stegocarpous plants differ from the typical $P$. subsessile in cucullate calyptra, greenish color of plants, relatively short and weakly serrulate awn and by in general less developed lamellae. By gametophytic characters and calyptra they are more similar to P. kozlovii. All these 'atypical $P$. subsessile' are from Altaisky Territory.

3) 'debatable P. kozlovii' (Fig. 2, columns 1418; Fig. 3, D-E; Fig. 5 D-G). Tufts yellowish-green, not hoary. Leaves (0.5-)0.6-1.7 x 0.4-1 mm (perichaetial leaves up to $2.3 \times 1.1 \mathrm{~mm}$ ), with relatively short and weakly serrulate hyaline awn. Awn (0.1-) 0.3-1.1(-1.3) mm long, usually shorter than lamina; the ratio awn:lamina length (0.2-)0.3-0.9 (-1.1). Median laminal cells quadrate to shortly rectangular, 12-18 x 14-27(-36) $\mu \mathrm{m}$; smooth to weakly mamillose or papillose on dorsal side. Ventral lamellae 2; in upper and perichaetial leaves 4-6 cell high, in median leaves 1-3 cell high, on lower leaves lamellae often lacking at all. Lamellae cells smooth to mamillose. Calyptra cucullate. Seta above vaginula $0.3-0.4(-0.8) \mathrm{mm}$ long. Capsule with beak about $0.2 \mathrm{~mm}$, without separating operculum, but with with 2-4 rows of 'marking cells' in position of annulus; 'marking cells' small, 9-14x12-23 $\mu \mathrm{m}$, abruptly or gradually transiting to large exothecial cells (18-27 x 45-70 $\mu \mathrm{m}$ in mid-urn).

So, in gametophytic characters and calyptra these plants are close to 'atypical P. subsessile' specimens, but they are cleistocarpous. All samples are from Altaisky Territory. The samples are in agreement with the descriptions of $P$. kozlovii from Saratov Region (Abramova \& al., 1973); but according to Zander (2003) they belong to Pterygoneurum subsessile var. kieneri.

4) 'typical P. kozlovii' (Fig. 2, columns 19-24; Fig. 3 F-I; Fig. 5 H-J; Fig. 6 C-D). Tufts yellowish-green, not hoary. Leaves (0.6-)0.7-1.6 x 0.3$0.8 \mathrm{~mm}$ (perichaetial leaves up to $2.0 \times 1.1 \mathrm{~mm}$ ) with weakly serrulate hyaline awn. Awn length from 0.2 to $1.7 \mathrm{~mm}$ long, usually shorter than lamina; the ratio awn:lamina length 0.3-1.0(-1.2). Median laminal cells quadrate to shortly rectangular, $12-16 \times(14-) 16-27 \mu \mathrm{m}$; smooth to strongly mamillose or papillose on dorsal side (one sample has rather bigger cells - 19-26 x 19-27 $\mu \mathrm{m})$. Ventral lamellae 2, low and often implicit, often present only in perichaetial leaves, up to 6 cell high (up to 10 cell high in Yakutian plants); lamellae cells smooth to strongly papillose. Calyptra cucullate. 


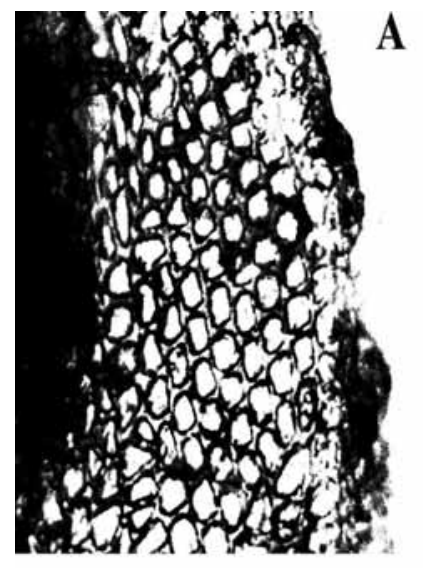

A
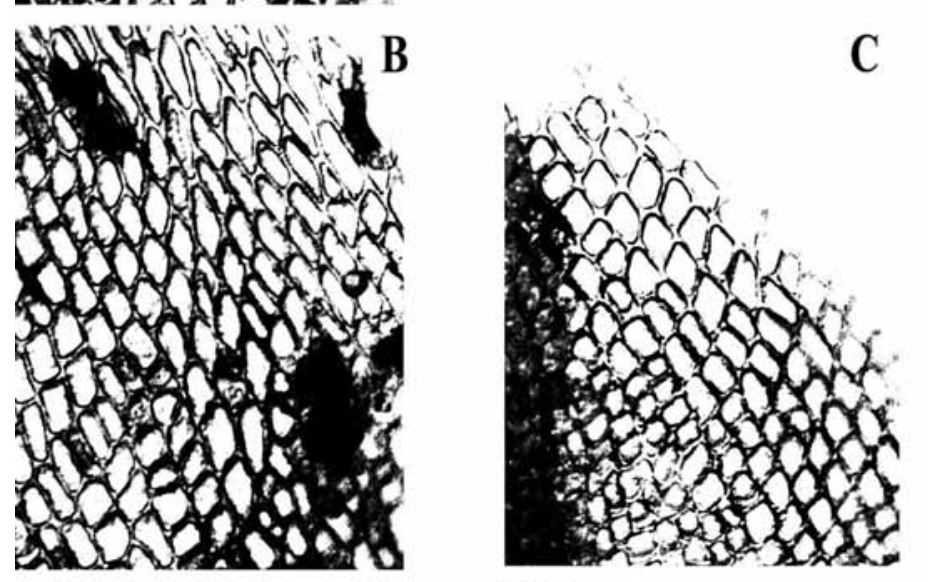

Fig. 7. Leaf areolation from different plants of Pterygoneurum
subsessile (Brid.) Jur. and P. kozlovii Lazar., foto from microscope
on x110. A - "typical P. subsessile", B-D - "atypical P. subsessile",
E-G - "debatable P. kozlovii", H-J - "typical P. kozlovii", description
in text. (A from Kazakhstan, 2. B-J from Altaisky Terrytory: B -
from plant 7, C-10, D-11, E-17, F \& G - 14, H-20, I \& J-22).
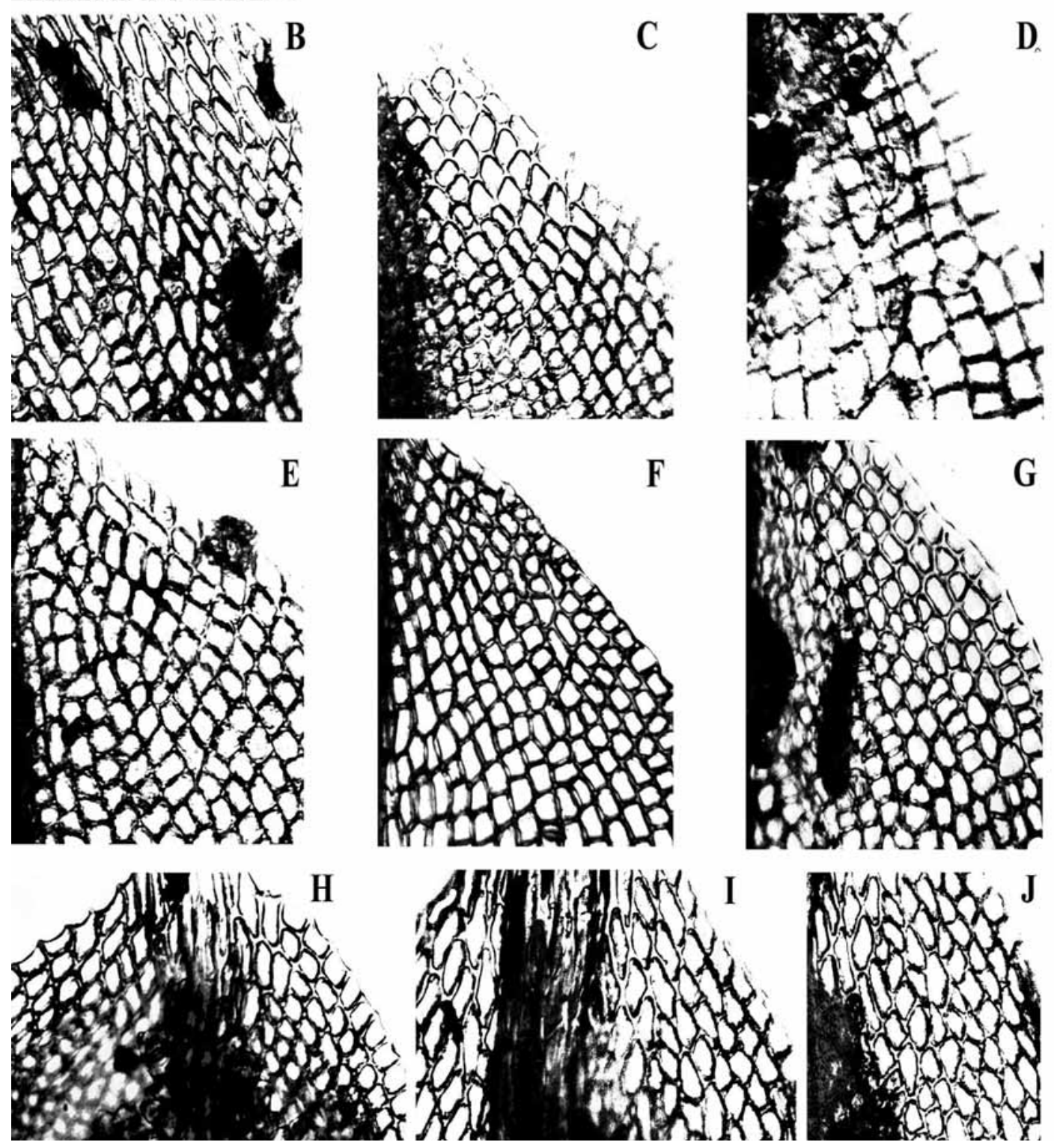


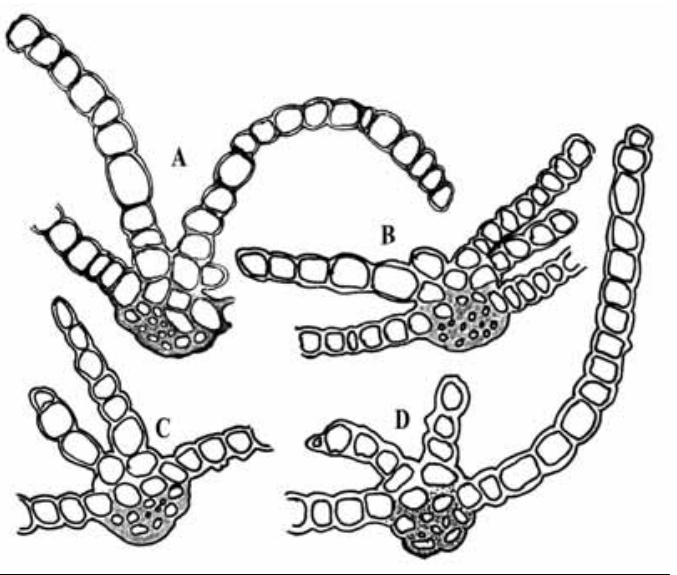

Seta above vaginula $0.06-0.15 \mathrm{~mm}$ long. Capsule with beak about $0.06-0.2 \mathrm{~mm}$, without separating operculum and any 'marking cells' in annulus position. Exothecial cells 18-32(-45) x 54-90 $\mu \mathrm{m}$ in mid-urn. Upper exothecial cell variable in shape in different plants: either cells gradually shortened towards beak (Fig. $5 \mathrm{~J}$ ), or several rows of small cells at beak base abruptly delimited, but the beak itself being formed by elongate cells (Fig. $5 \mathrm{H}$ ).

The plants from Yakutia (Fig. 2, column 24 ) differ from plants of Altaisky Territory only by somewhat taller lamellae and more strongly papillose cells.

5) Two cleistocarpous Pterygoneurum plants were found in tuft of 'typical P. subsessile' in a specimen from Kazakhstan (Fig. 2, column 25; Fig. 3 J; Fig. 5 K). In gametophyte features the plants are almost identical to 'typical $P$. subsessile' from the same tuft: leaves are with sharply serrulate long awn; the ratio awn:lamina length is 1.52.9; lamina cells are 14-16 x 14-16 $\mu \mathrm{m}$, strongly papillose; the lamellae are 2-4, tall, 7-19 cell high. The only difference in gametophyte from the 'typical P. subsessile' from the same tuft is that the plants have papillose lamellae cells. Seta above vaginula is $0.3 \mathrm{~mm}$ long. Cleistocarpous capsula has neither annulus of 'marking cells', nor beak; exothecial cells in mid-urn are 18-34 x 54-70 $\mu \mathrm{m}$, gradually transiting into small quadrate cells (9$12 \times 9-18 \mu \mathrm{m})$ on the top of the capsula.

In the spores, costa transverse sections and shape and size of lamina cells all the studied specimens were more or less similar. The spores are ((27-)30-36(-40) $\mu \mathrm{m})$, brown and papillose. Costa in transverse section has 2 guide cells and only
Fig. 8. Leaf transverse sections from of Pterygoneurum subsessile (Brid.) Jur. and P. kozlovii Laz. A-B - "typical P. subsessile", C-D - "typical P. kozlovii". (A, C, D from Altaisky Terrytory: A - from plant 5; C - 21, D - 23. B from Central Yakutia, 1).

dorsal stereid band (Fig. 8).

Lamina cells (Fig. 6-8) are smooth to mamillose or papillose on dorsal side; the cells below apex are rhomboidal, towards the base gradually becoming heterogeneously quadrate and shortly rectangular, 9-16(-18)x(9-)11-27(-36) $\mu \mathrm{m}$, at leaf base thinwalled and enlarged, to $18-30 \times 36-72 \mu \mathrm{m}$. Regarding cell size the group of 'typical P. subsessile' is the most homogeneous (Fig. 4 A); other groups have larger variations. Two samples, from 'atypical $P$. subsessile' and 'typical P. kozlovii' are outstanding by laminal cells shape and size (Fig. 4B,D; Fig. 6C; Fig. 7D): all mid-leaf cells thin-walled and big, to $18-26 \times 18-27 \mu \mathrm{m}$; but in other characters these plants are in agreement with their groups.

Bar graphs (Fig. 2) show the absence of correlation between the character of operculum dehiscence and the gametophyte characters. There is an indistinct correlation between calyptra shape, awn length/lamina lendth ratio and lamellae height: plants with mitrate calyptra have relatively more long awn and in general more high lamellae. But in any group variation limits of awn/lamina lendth ratio and lamellae height overlap with variation limits of adjacent groups.

Variation in sporophyte and gametophyte characters is not always correlated: 'typical $P$. subsessile' and 'atypical P. subsessile' are similar in sporophyte, but differ in gametophyte and calyptra characters; 'atypical P. subsessile'-'debatable P. kozlovii'-' typical P. kozlovii' demonstrate great variation in sporophyte structure and a relative stability of the gametophytic characters.

It is possible to arrange specimens of $P$. subsessile - P. kozlovii complex as a series: 'typical P. subsessile' -'atypical P. subsessile'-'debatable P. kozlovii'-' typical P. kozlovii'. However, the cleistocarpous Pterygoneurum from Kazakhstan (specimen 25) is out of this series: it has longawned leaves with high lamellae, but cleistocarpous capsula even without 'marking cells'.

Plants of these four types occur in various combinations in the same habitats (Figs. 1-2, Tabl. 1). According to literature, P. subsessile 
and P. kozlovii are different in their ecology (Smarda, 1952; Abramova \& al., 1973; McIntosh, 1989): P. subsessile is common in a broad range of xeric habitats - on soil and sand in steppe and desert communities, on fine earth on dry rocky outcrops, often on limestones, while P. kozlovii also occurs in xeric areas, preferring more or less saline habitats. This is also true in Altaisky Territory: P. subsessile is not a rare species (Nozinkov, 2002), it occurs on soil in different steppes and along planted forest belts. At the same time 'typical P. kozlovii', 'debatable $P$. kozlovii' and 'atypical $P$. subsessile' were found only in solonetz and solonchak communities, with salinization degree 14-21. 'Typical P. subsessile' in saline habitat (salinization degree more than 17) was recorded only once. $\mathrm{Nu}$ merous Pterygoneurum-samples from different desert communities of Kazakhstan (from transect Ust-Kamenogorsk - Lepsi - Topar - Alma-Ata) are mainly Pterygoneurum ovatum (Hedw.) Dix., rarely in mixture with $P$. subsessile. Cleistocarpous Pterygoneurum plants were found only in the sample from the described more or less saline habitat. But in Yakutia P. kozlovii was collected in non-saline habitat and in mixture with P. subsessile. Substrate of the samples from Altaisky Territory and Kazakhstan was calcareous, 'boiling' with $\mathrm{HCl}$, it is not so with sample substratum from Yakutia. Preceding samples from Yakutia, Indigirka River (LE) were also collected in non-saline habitats: Artemisia-Koeleria steppe on steep slope (16.VI.1976, Afonina); dry Artemisia-Koeleria-Helictotrichon steppe with lichens on flat surface near a top (18.VI.1976, Afonina); Helictotrichon-Poa meadow steppe (1.VII.1976, Afonina).

\section{DISCUSSION}

Both typical morphotypes of $P$. subsessile and $P$. kozlovii and intermediates between them occur in Altaisky Territory. The 'atypical $P$. subsessile', 'debatable P. kozlovii' and typical $P$. kozlovii grow almost exclusively in more or less saline habitats, occurring usually side by side with each other in one tuft.

It seems that the situation found in Altaisky Territory is not unique: at least the mentioned above inconsistencies in descriptions of $P$. kozlovii from different regions can be interpreted in this way. However the variation within the populations of $P$. kozlovii is not well described mainly due to the overall rarity of this small cleisocarpous moss.

Intermediate morphotypes found in Altaisky Territory are not the only possible ones; two more cases are known (and in both cases the plants were found in tufts with the 'typical P. subsessile'):

(1) cleistocarpous plants with 'marking cells' and rigid long-awned leaves that were described as Pterygoneurum subsessile var. kieneri from $\mathrm{Ne}$ braska (Zander, 2003);

(2) cleistocarpous plants without 'marking cells' and rigid long-awn leaves (our sample from Kazakhstan, 'plant 25').

At the same time, Yakutian collections include only typical $P$. subsessile and typical P. kozlovii without any intermediates, they grow in non-saline habitats and sometimes in the same microsites.

Hypothesis about the hybrid origin of $P$. kozlovii from Pterygoneurum ( $P$. subsessile or $P$. ovatum) and Tortula acaulon (=Phascum cuspidatum) was suggested repeatedly (Lazarenko, 1946; Corley \& al., 1981), and the same explanation was proposed for $P$. subsessile var. kieneri (Guerra \& al., 1994; Zander, 2003). However no direct evidence has been obtained for that so far.

According to the present data, the hypothesis of hybrid origin seems to be insufficient for explanation of all these cases, although it may take place as well. However the strong ecolocical plasticity can be explained also by the blocking of the last stages of the sporophyte ontogenesis by toxic concentrations of potassium chloride. Are all the clestocarpous Pterygoneurum genetically identical or some of population comprise the aberrations of $P$. subsessile, and if so - did they originate once or few or many times? Present data do not answer these questions, but allow to put them for the further checking.

\section{ACKNOWLEDGEMENTS}

I am very grateful to Elena Ivanova for arranging my field trip to Yakutia, to Andrej Korolyuk for the organization of expeditions to Altaisky Territory and Kazakhstan and his kindly continuous comments on the vegetation of territories. The work is partly supported by RFBR, grants 05-0448780 \& 06-04-48787. 


\section{LiTERATURE CITED}

[ABRAMOVA, A.L., L.S. BLAGODATSKIH \& L.A. CZEREPANOVA] АБРАМОВА Л.А., Л.С. БЛАГОДАТСКИХ, Л.А. ЧЕРЕПАНОВА 1973. Обзор рода Pterygoneurum Jur. (Musci) в CCCP. - [The genus Pterygoneurum Jur. (Musci) in the URSS] Новости сист. низи. pacm. [Novosti Sist. Nizsh. Rast.] 10: 305-316.

[ABRAMOVA, A.L. \& TS. TSEGMED] АБРАМОВА А.Л., Ц. ЦЭГМЭД 1989. К бриофлоре Монгольского Алтая. - [On the bryoflora of Mongolian Altai] Новости Cист. Низи. Pacm. [Novosti Sist. Nizsh. Rast.] 26: 136-146.

AFONINA, O.M., L.I. BREDKINA \& I.I. MAKAROVA] АФОНИНА О.М., Л.И. БРЕДКИНА, И.И. МАКАРОВА 1979. Мхи и лишайники лесостепного ландшафта в среднем течении р. Индигирки. - [Mosses and lichens of forest-steppe landscape in the middle course of Indigirka River] Новости сист. низи. pacm. [Novosti Sist. Nizsh. Rast.] 16: 175-186.

[BABENKO, L.A., V.V. FEDYAEVA] БАБЕНКО Л.А., В.В. ФЕДЯЕВА 2001. Биоразнообразие Нижнего Дона: бриофлора. - [Biodiversity of Lower Don River: bryoflora] Ростов-на-Дону, Ростовский гос.ун-m [Rostov-naDone, Rostovsk.Gos. Univ.]: 1-103 pp.

[BACHURINA, G.F.] БАЧУРИНА Г.Ф. 1960 До флори мохів південно-західноі частини Одеськоі області. -[On the moss flora of south-western part of Odessa Region] Укр.бот. журн. [Ukr. Bot. Zhurn] 17 (2): 83-88.

[CHEREPANOVA, L.A.] ЧЕРЕПАНОВА Л.А. 1971. Материалы к флоре мхов Саратовской области. - [Contributions to the moss flora of Saratov Region] Бот. журн. [Bot. Zhurn.] 56 (12): 1827-1836.

CORLEY, M.F.V., A.C. CRUNDWELL, R. DÜLL, M.O. HILL \& A.J.E. SMITH 1981. Mosses of Europe and the Azores; an annotated list of species, with synonyms from the recent literature. - J. Bryol. 11: 609-689.

[GOLUB, V.B., D.N. KARPOV, A.N. SOROKIN \& L.F. NIKOLAJCHUK] ГОЛУБ В.Б., Д.Н. КАРПОВ, А.Н. СОРОКИН, Л.Ф. НИКОЛАЙЧУК 2005. Сообщества класса Festuco-Puccinellietea Soo ex Vicherek 1973 на территории Евразии. - [Communities of class FestucoPuccinellietea Soo ex Vicherek 1973 on Eurasia terrytory] В кн.: Растительность России. Санкт-Петербург [In: Vegetation of Russia. St. Peterburg] 7: 59-75.

GUERRA, J., R.M. ROS \& M.J. CANO. 1994 Pterygoneurum subsessile (Brid.) Jur. var. kieneri Hab. (Musci, Pottiaceae), a putative hybrid. - Nova Hedwigia, 58: 507-510.

HABEEB, H. 1949. A new moss from Nebraska. - Rhodora 51: 128 .

[IGNATOV, M.S. \& E.A. IGNATOVA] ИГНАTOB M.C., Е.A. ИГНАТОВА 2003. Флора мхов средней части европейской России. Т. 1. Sphagnaceae-Hedwigiaceae. [Moss flora of the Middle European Russia. Vol.1. Sphagnaceae-Hedwigiaceae] M., KMK [Moscow, KMK]: 1-608.

KOROLYUK, A. 1999. Phytosociological report from the saline habitats in SW Siberia and N Kazachstan. - In: Halophyte uses in different climates I. (ed. Lieth et al.). Lieden, The Nitherlands.: 133-146.
[KOROLYUK, A.YU. \& L.M. KIPRIJANOVA] КОРОЛЮК А.Ю., Л.М. КИПРИЯНОВА 1998. Продромус естественной растительности юго-востока Западной Сибири (Алтайский край и Новосибирская область). [Prodromus of intact vegetation of south-east West Siberia (Novosibirst Region and Altaisky Territory)] В кн.: Ботанические исследования Сибири и Казахстана. Барнаул. [In: Botanical investigations of Siberia and Kazakhstan. Barnaul] 4: 63-82.

[KOROLYUK, A.YU., S.A. PRISTIAZNYUK \& S.G. PLATONOVA] КОРОЛЮК А.Ю., С.А. ПРИСТЯЖНЮК, С.Г. ПЛАТОНОВА 2000. Сообщества пустынного типа на юго-востоке Западной Сибири. - [Communities of desert type in south-east of West Siberia] Бот. журн. [Bot. Zhurn.] 85 (2): 97-105.

[KOROLYUK, A.YU.] КОРОЛЮК А.Ю. 1993. Синтаксономия растительности юга Западной Сибири. 1. Гигрофильная и галофильная растительность. - [Syntaxonomi of vegetation of south West Siberia. 1. Hygrophilous and halophilous vegetation] Новосибирск, Деп. в ВИНИТИ [Novosibirsk, deposited in ICSTI], № 1643-B93: $1-33$.

[KOROLYUK, A.YU.] КОРОЛЮК А.Ю. 2000. Подходы к разработке экологических шкал растений южной Сибири. - [The approaches to working up of ecological scales for plants of South Siberia] В кн.: Проблемы создания ботанических баз данных. M. [In: The problems of botanical databases creations. Mockow]: 26-29.

[LAZARENKO, A.S.] ЛАЗАРЕНКО А.C. 1946. Бріологічні нотатки. - [Bryological notes $]$ Бот. журн. АН УРСР [Bot. Zhurn.(Kiev)] 3 (3-4): 61-63.

[LAZARENKO, A.S.] ЛАЗАРЕНКО А.C. 1955. Определитель лиственных мхов Украины. - [Handbook of mosses of Ukraine] Киев, Наукова думка [Kiev,Naukova Dumka]: 1-468.

MCINTOSH, T.T. 1989. Bryophyte records from the semiarid steppe of northwestern North America, including four species new to North America. - Bryologist 92: 356-362.

[METHODICAL instructions of ecological estimation of forage reserve of forest-steppe and steppe zones of Siberia by plant cover] МЕТОДИЧЕСКИЕ указания по экологической оценке кормовых угодий лесостепной и степной зон Сибири по растительному покрову. 1974. - M. [Moscow]: 1-246.

[NOZHINKOV, A.E.] НОЖИНКОВ А.Е. 2002. Бриевые мхи равнинной части Алтайского Края. - [Mosses of plain part of Altai Region] В кн.: Проблемы бриологии на рубеже веков. Материаль межд. совещания, посвященного 90-летию со дня рождения Р.Н. Шлякова (20.06.1912) и И.И. Абрамова (14.07.1912), СанктПетербургб 4-6 ноября 2002 г. [In: Problems of bryology at the boundary of centuries. Proceedings of the international conference devoted to 90-th anniversary of R.H. Schljakov (20.06.1912) and I.I. Abramov (14.07.1912), Saint Peterburg, November 4-6, 2002]: 45-46.

[SAVICZ-LUBITSKAYA, L.I. \& Z. N. SMIRNOVA] CAВИЧЛЮБИЦКАЯ, Л.И., З.Н. СМИРНОВА 1970. Опре- 
делитель листостебельных мхов СССР. Верхоплодные мхи. - [The Handbook of mosses of the USSR. The mosses apocarpous.] Л., Наука [Leningrad, Nauka]: 1-824.

[SAMOILOV, YU.I.] САМОЙЛОВ Ю.И. 1973. Некоторые результаты сравнения экологических шкал Раменского, Элленберга, Хундта и Клаапа - [Some results of comparison of the ecological scales of Ramensky, Ellenberg, Hundt and Klaap] Бот. журн. [Bot. Zhurn.] 58 (5): 646655.

SMARDA, J. 1952. Prispevek k poznani fytocenos slanych pud na jz. Slovensku. - Preslia 24 (1): 95-111.

TAN, B. C., J.-C. ZHAO \& R.-L. HU. 1995. An updated checklist of Mosses of Xinjiang, China. - Arctoa 4: 1-14.

TSEGMED, TS. 2001. Checlist and distribution of mosses in Mongolia - Arctoa 10: 1-18.

VANEK, R. 1952. Pterygoneurum Smardaeanum Vanek sp. nov. - Preslia 24: 211-215

WALLFISCH, R. 2001. Pterygoneurum kozlovii - new for Romania. - Acta Horti Botanici Bucurestiensis 29: 133134.

ZANDER, R.H. 2003. Pterygoneurum. - Bryophyte Flora of North America, Provisional Publication. Buffalo Museum of Science. www.buffalomuseumofscience.org/BFNA/ bfnamenu.htm 